\title{
KAJIAN ANTROPOLOGI HUKUM DENGAN ILMU SOSIAL LAINNYA
}

\author{
RAHMATPUTRA \\ Email:rahmat.putara22@gmail.com \\ NO.BP:2010003600343 \\ Universitas Ekasakti Padang -Fakultas Hukum
}

\section{A.PENDAHULUAN}

Antropologi merupakan disiplin ilmu yang luas di mana humaniora, sosial, dan ilmu pengetahuan alam digabung dalam menjelaskan apa itu manusia dan artinya menjadi manusia. Antropologi dibangun berdasarkan pengetahuan dari ilmu alam, termasuk penemuan tentang asal usul dan evolusi Homo sapiens, ciri-ciri fisik manusia, perilaku manusia, variasi di antara berbagai kelompok manusia, bagaimana masa lalu evolusi Homo sapiens telah memengaruhi organisasi dan budaya sosial. Serta dari ilmu-ilmu sosial, antropologi memelajari organisasi hubungan manusia sosial dan budaya, sistem keturunan dan hubungan kekerabatan, spiritualitas dan religi, lembaga, konflik sosial, dan lainlain. Antropologi awal berasal dari Yunani klasik dan Persia yang memelajari dan mencoba untuk memahami keragaman budaya yang dapat diamati. Pada saat ini, antropologi (akhir abad ke-20) telah menjadi sentral dalam pengembangan beberapa bidang interdisipliner baru seperti ilmu kognitif, studi globalisasi, genetik, dan berbagai penelitian etnis.

antropologi sebagai disiplin ilmu terus berkembang, tidak hanya padatataran teoritis tetapi juga sebagai ilmu terapan yang mampu memberikan masukan bagi para pembuat keputusan dalam menentukankebijakan pembangunan. Di Indonesia, perkembangan antropologi sebagaidisiplin ilmu yang dipelajari para mahasiswa di perguruan tinggi masih tergolong baru. Salah satu tokoh penting dalam perkembangan antropologi di Indonesia adalah Koentjaraningrat, sehingga dapat dikatakan bahwa iamerupakan bapak antropologi di Indonesia (Suparlan, 1988). Sebagai tokoh sentral di Indonesia, Koentjaraningrat telah meletakkan dasar-dasarantropologi Indonesia. 
Beberapa tugas yang berhasil diembannya adalah 1) mengembangkan prasarana akademis ilmu antropologi; 2) mempersiapkan dan membina tenaga-tenaga pengajar dan tenaga ahli di bidang antropologi; dan 3) mengembangkan bahan pendidikan untuk pembelajaran bidang

antropologi (Masinambow, 1997).

Sebagai disiplin ilmu, antropologi merupakan kajian yang multidisipliner yang berupaya mengkaji aspek manusia secara menyeluruh (holistik). Secara historis, antropologi berkembang dari suatu deskripsi hasil-hasil laporan perjalanan para penjelajah dan penjajah tentang kehidupan manusia di daerah yang disinggahi para penjelajah, atau kehidupan salah satu suku bangsa yang tinggal di daerah jajahan. Deskripsi tersebut dikenal dengan nama etnografi. Dalam perjalanannya kemudian, antropologi berkembang sebagaimana keberadaannya sekarang baik di negara-negara Eropa Barat, Amerika maupun di Asia. Beberapa cabang antropologi yang dikenal secara luas saat ini adalah antropologi fisik atau biologi, antropologi sosial, dan antropologi budaya. Di sisi yang lain, antropologi juga merupakan bidang ilmu terapan sehingga hasil kajiannya dapat dimanfaatkan sebagai masukan dalam pengambilan keputusan untuk keperluan pembangunan, terutama dalam pembangunan sosial budaya, seperti antropologi pembangunan, antropologi kesehatan, antropologi ekonomi, dan sebagainya. 


\section{B.PEMBAHASAN}

Spesialisasi dalam bidang antropologi memungkinkan adanya mitra kerja sama antarbidang ilmu, yaitu antropologi dan bidang lain. Sosiologi merupakan salah satu bidang ilmu yang paling banyak disorot karena dianggap banyak persamaannya. Hal ini ditandai oleh kenyataan bahwa di beberapa universitas telah terjadi penggabungan jurusan menjadi satu jurusan saja yaitu jurusan antropologi-sosiologi atau sosiologi-antropologi. Di bawah ini diperlihatkan kepada Anda beberapa keterkaitan antara antropologi dengan beberapa bidang ilmu lainnya, seperti dengan ilmu administrasi, Ilmu Politik, IImu Sejarah, dan sebagainya.

\section{Hubungan Antropologi dan Sosiologi}

Hubungan antara Antropologi dan sosiologi pada satu sisi, memperlihatkan bahwa sebagian para ahli tidak lagi membedakan kedua ilmu tersebut secara ketat. Artinya beberapa fokus kajiannya dianggap sama bahkan beberapa paradigma yang digunakan untuk melihat suatu fenomena sosial pun dianggap tidak memiliki perbedaan. Kedua ilmu itu bisa saling menukar atau saling melengkapi baik menyangkut paradigma ataupun metode yang digunakan dalam mengungkap suatu fenomena sosial. Di pihak ini, perbedaan antropologi dan sosiologi hanya terjadi pada sejarah berdirinya masing-masing ilmu tersebut. Namun dalam perkembangan selanjutnya, kedua ilmu itu dapat saling melengkapi bahkan melebur diri menjadi satu ilmu. Pada universitas tertentu, antropologi dan sosiologi merupakan programstudi yang dikembangkan secara bersama-sama di bawah departemen.

\section{Hubungan Antropologi dan Ilmu Politik}

Perkembangan ilmu terus berlanjut, begitu pula dengan ilmu politik, yang mulai banyak menaruh perhatian terhadap berbagai fenomena budaya masyarakat yang terkait langsung atau tidak langsung. Keanggotaan partai politik di Indonesia sangat dipengaruhi oleh kondisi budaya masyarakatnya. Budaya masyarakat di Indonesia yang cenderung patrimonial sangat berpengaruh pada 
sistem budaya politiknya. Untuk itu, untuk lebih dapat memahami perilaku politik masyarakat di Indonesia, Anda perlu belajar tentang kebudayaan masyarakat di Indonesia, yang terdiri dari bermacam- macam suku bangsa dan masing-masing suku bangsa tersebut memiliki kebudayaannya yang khas. Untuk keperluan tersebut, antropologi mempunyai peran dalam kaitannya dengan kajian ilmu politik, karena mampu mengungkap kebudayaan suatu masyarakat yang akan menjadi tempat bagi perilaku politik.

\section{Hubungan Antropologi dan Ilmu Ekonomi}

Ilmu Ekonomi yang mengkaji fenomena ekonomi modern lebih didasari oleh pemikiran-pemikiran Barat atau Ero-Eropa. Persoalannya adalah bilamana pemikiran-pemikiran ekonomi diterapkan pada setiap masyarakat terutama masyarakat yang masih sederhana atau negara terutama negara- negara berkembang tidak selamanya akan sesuai karena dilatarbelakangi olehfaktor cara pandang yang berbeda pada kehidupan ekonominya. Perhitungan ekonomi modern tidak selamanya dapat diterapkan pada sistem ekonomimasyarakat non Barat. Keragaman budaya pada setiap masyarakat atau suku bangsa memperlihatkan pula adanya keragaman dalam strategi kehidupan ekonominya. Keragaman pada sistem ekonomi dapat dilihat pada sistem produksi apakah bercocok tanam sebagai petani, nelayan, peternakan, dan sebagainya. Begitu pula keragaman ini dapat dilihat pada sistem tukar menukar atau sistem jual beli barang.

Pada kondisi seperti di atas, antropologi sangat diharapkan perannyauntuk dapat menjembatani pemikiran ekonomi modern dan pemikiran ekonomi lokal. Pembangunan ekonomi masyarakat di negara-negara berkembang tidak akan berjalan dengan baik bilamana tanpa diikuti oleh pertimbangan aspek budaya lokal terutama yang terkait dengan pola pikir kehidupan ekonominya. Terdapat perbedaan pandangan, anggapan, pengetahuan, persepsi pada masyarakat industri dengan masyarakat nonindustri seperti pertanian. Oleh karena itu perlu kehati-hatian para perencana pembangunan yang mencoba mengadopsi pemikiran atau teknologi yang datang dari masyarakat industri (negara-negara Barat) bagi kepentingan untuk meningkatkan kesejahteraan masyarakat nonindustri. 
4. Hubungan Antropologi dan Ilmu Administrasi

Pentingnya antropologi bagi Ilmu Administrasi adalah terkait dengan kebutuhan Ilmu Administrasi untuk memecahkan persoalan-persoalan administrasi pemerintahan. Kondisi sistem administrasi pemerintahan yang dianggap masih kurang baik oleh sebagian pihak, seperti masalah pemilikan tanah, membutuhkan pemecahan bukan saja dari pihak pegawai atau para admonistartur tetapi juga karena aspek yang bersumber pada latar belakang. sosial budaya masyarakat yang belum menganggap penting masalahadministrasi.

5. Hubungan Antropologi dan Arkeologi serta Ilmu Sejarah

Pada dasarnya arkeologi bertujuan menyingkap sejarah kebudayaan manusia dari mulai kebudayaan kuno pada jaman purba seperti kebudayaan Mesopotamia dan kebudayaan Mesir Kuno. Di Indonesia, Arkeologi memfokuskan perhatiannya kepada kebudayaan di Indonesia pada masa Hindu yang hidup sekitar abad ke 4 hingga abad ke 16. Hasil penelitian arkeologi terhadap bahan bekas reruntuhan atau alat-alat peninggalan kerajaan Hindu di Indonesia adalah sebuah deskripsi sejarah manusia yang kemudian dapat digunakan oleh antropologi sebagai bahan untuk merekonstruksi sejarah asal-mula makhluk manusia. Dilihat dari batasan kajiannya, antropologi terlihat lebih luas karena tidak hanya memfokuskan pada benda-benda peninggalan (artifak) saja, melainkan juga pada sistem ide (gagasan dan sistem tingkah laku).

Kesulitan di dalam merekonstruksi kembali kehidupan dan persebaran kebudayaan, antropologi dan ilmu sejarah saling bertukar metode dan teori untuk lebih dapat memahami masyarakat pada umumnya. Begitu pula penggambaran tentang hasil penelitian keduanya bisa saling melengkapi sesuai bagi tujuan tertentu. 


\section{C.PENUTUP}

Antropologi adalah salah satu cabang ilmu pengetahuan sosial yang mempelajari tentang budaya masyarakat suatu etnis tertentu. Antropologi lahir atau muncul berawal dari ketertarikan orang-orang Eropa yang melihat ciri-ciri fisik, adat istiadat, budaya yang berbeda dari apa yang dikenal di Eropa. Terbentuklah ilmu antropologi dengan melalui beberapa fase. Antropologi lebih memusatkan pada penduduk yang merupakan masyarakat tunggal, tunggal dalam arti kesatuan masyarakat yang tinggal daerah yang sama, antropologi mirip seperti sosiologi tetapi pada sosiologi lebih menitik beratkan pada masyarakat dan kehidupan sosialnya. Di antara ilmu-ilmu sosial, dan alamiah, antropologi memiliki kedudukan, tujuan, manfaat yang unik karena bertujuan dan bermanfaat dalam merumuskan penjelasan-penjelasan tentang perilaku manusia yang didasarkan pada studi atas semua aspek biologis manusia dan perilakunya di semua masyarakat. Objek kajian sosiologi adalah masyarakat manusia terutama dari sudut hubungan antar manusia dan proses- proses yang timbul dari hubungan manusia dalam masyarakat. Dalam antropologi budaya mempelajari gambaran tentang perilaku manusia dan konteks sosial budayanya.

\section{DAFTAR PUSTAKA}

Conrad, Philip Kottak. (1991). Anthropology: The Exploration of Human Diversity. Edisi ke 5. New York: McGraw-Hill, Inc.

Harsojo. (1984). Pengantar Antropologi. Cetakan kelima. Jakarta: Penerbit Rineka Cipta

Koentjaraningrat. (1996). Pengantar Antropologi I. Jakarta: Penerbit Rineka Cipta.

Koentjaraningrat. (1982). Sejarah Teori Antropologi. Jakarta: Penerbit Rineka Cipta.

Masinambow, E.K.M. (1997). Koentjaraningrat dan Antropologi di Indonesia. Jakarta: AAl dan Yayasan Obor Indonesia.

Suparlan, Parsudi. (1988). Prof. Koentjaraningrat: Bapak Antropologi Indonesia. Makalah untuk menyambut purna kedinasan Koentjaraningrat. 